\title{
Torture by the Nigerian Police Force: International Obligations, National Responses and the Way Forward
}

\author{
Elkanah Babatunde*
}

\begin{abstract}
Police brutality has become rife in Nigeria and is regarded by some as a normal part of police operations. This is despite the fact that the Nigerian Constitution provides for the guarantee of the right to dignity and the protection against torture and inhuman or degrading treatment. Nigeria is also party to some international treaties such as the International Covenant on Civil and Political Rights, the Convention against Torture and other Cruel, Inhuman or Degrading Treatment or Punishment and the African Charter on Human and Peoples' Rights which expressly prohibit torture and other cruel, inhuman and degrading treatment. This raises the question whether police brutality in Nigeria amounts to torture and / or other cruel, inhuman or degrading treatment and whether the existing legal framework sufficiently prevents and punishes the perpetrators of these acts.
\end{abstract}

\section{Introduction}

Nigeria is party to international treaties including the International Covenant on Civil and Political Rights (ICCPR), ${ }^{1}$ the Convention against Torture and other Cruel, Inhuman or Degrading Treatment or Punishment (CAT) ${ }^{2}$ and the African Charter on Human and Peoples' Rights (ACHPR). ${ }^{3}$ Article 7 of the ICCPR, Article 2(1) of the CAT and Article 5 of the ACHPR each prohibit torture

* The author is an LL.M candidate at The University of Cape Town in Cape Town, South Africa.

1 International Covenant on Civil and Political Rights, 16 December 1943, 1966, 999 UNTS 171. This treaty was ratified by Nigeria on 29 July 1993.

2 United Nations Convention against Torture, 10 December 1984, 1465 UNTS 85. This treaty was ratified by Nigeria on 28 June, 2001.

3 African Charter on Human and Peoples' Rights, 28 June 1981, 1520 UNTS 217. This treaty was ratified by Nigeria on 22 June, 1983. 
and other cruel, inhuman and degrading treatment. States party to these treaties have an obligation to prohibit torture and protect their citizens from it. ${ }^{4}$

This article discusses police brutality in Nigeria and the extent to which such brutalities are considered torture and other prohibited forms of treatment. The existing legal structure and its inefficiency and incompetency to curb this abuse of police power is also discussed in this work. It maintains that Nigeria is in breach of its obligation to prevent torture and other cruel, inhuman or degrading treatment. The article goes further to examine how Nigeria can be held accountable for this breach and the way forward for ensuring accountability and putting an end to impunity.

This article has been divided into three major sections. The first section takes a look at the history and functions of the Nigerian Police Force. The aim of this section is to trace the origin of police brutality in Nigeria and its continued existence. The second section will focus on Nigerian law, with emphasis on the Nigerian Constitution and the Police Act, with the aim of exploring whether an adequate legal framework exists within the Nigerian legal system for the prohibition and punishment of torture and other inhuman treatment. The third section will focus on the enforceability of international treaties in Nigeria. This section goes further to examine the prohibition of torture and other cruel, inhuman or degrading treatment under international human rights law. This section examines the definition of torture and whether the acts perpetuated by the Nigerian Police amount to torture under international law. The Nigeria Police Force Order 237 will be examined 'vis-à-vis' international human rights law and it shall be determined whether it constitutes an exception to the international law prohibition against torture and other inhuman treatment. In conclusion, an argument will be made for the enactment of an anti-torture law in Nigeria. This law will provide the necessary legal framework for the use of force by the police, the punishment of perpetrators of torture and other cruel, inhuman or degrading treatment and provision of compensation for the victims of torture and other cruel, inhuman or degrading treatment.

The article draws from the work of scholars both within Nigerian constitutional law and international human rights law. A great reliance on facts will be placed on the research that has been carried out by Amnesty International (Amnesty) and Human Rights Watch (HRW) on the acts of brutality by the Nigerian

Article 7, International Covenant on Civil and Political Rights, 29 July 1993, 999 UNTS 171; Article 2, Convention against Torture, 10 December 1984, 1465 UNTS 85; Article 5 African Charter on Human and Peoples' Rights, 28 June 1981, 1520 UNTS 217. 
Police. This is due to the fact that the research conducted by these organisations on police brutality in Nigeria is extensive and involves direct interviews with victims of police brutality. The research of these organisations on police brutality was also conducted on a nationwide basis and offers a view of the acts perpetrated by the different command units of the Nigerian Police, rather than just a few commands of the Nigeria Police Force.

\section{Origin of Police Brutality in Nigeria}

The Nigerian Police Force (NPF) is one of the organs of the Federal Republic of Nigeria (Nigeria) tasked with the responsibility of law enforcement. ${ }^{5} \mathrm{It}$ is saddled with primary responsibility for the prevention and detection of crime in Nigeria. ${ }^{6}$ In order to carry out these functions, NPF is vested with the power to arrest, interrogate and, where necessary, detain suspected criminals. ${ }^{7}$

NPF emerged from the various pockets of police units established by the colonial government in Imo State (in the South-Eastern part of Nigeria) in 1820, Kano (in the North) in 1879 and Lagos (in the West) in 1896. ${ }^{8}$ These separate forces were called 'constabularies' and merged into the Southern Region and the Northern Region Police Force in the early 1900s.' These regional police forces were unified as the Nigerian Police Force in April 1930. ${ }^{10}$

As earlier mentioned, NPF was formerly made up of constabularies. These constabularies, as the name implies, were primarily military in function ${ }^{11}$ and were used by the colonial government to silence opposition to its imperialist and domineering policies. ${ }^{12}$ The colonial police force in Nigeria was an instrument specifically designed by the colonial government to subjugate the masses and consolidate its colonial gains. ${ }^{13}$ For example, the establishment of the Royal Niger constabulary in Lagos was primarily to protect the economic interests of

Section 215 (2), 'Constitution of the Federal Republic of Nigeria' (1999).

Section 4, Police Act 1943, (Cap P19 Nigeria), 2004.

Part IV Police Act.

- <https://www.npf.gov.ng/zone9.php> on 14 April 2016.

- <http://www.nigeriapolicewatch.com/resources/about-the-nigeria-police/> on 5 May 2016.

Ehindero S, The Nigeria Police and buman rights, Ehindero Press Jos. 2005. 12.

Obaro O, 'The Nigeria Police force and the crisis of legitimacy: Re-defining the structure and function of the Nigeria Police', 10(8) European Scientific Journal, 2005, 421-436.

12 Obaro O, 'The Nigeria Police Force and the crisis of legitimacy: Re-defining the structure and function of the Nigeria Police', 426.

13 Mbaku J and Kimenyi M, 'Rent seeking and policing in colonial Africa' 8(3), Indian Journal of Science, 1995, 278. 
the British along the banks of River Niger. ${ }^{14}$ Although their publicly proclaimed function was to maintain peace and order, the definition of peace and order was the payment of tax to the colonial government and obedience to the consular authorities and warrant chiefs. ${ }^{15}$

It is clear that, the Nigerian Police Force was flawed from the very beginning. ${ }^{16}$ It was not established for the protection of the people nor was it established as a force responsible and accountable to the people of Nigeria. Indeed, the colonial authorities may have applauded the excesses of the police officers and even rewarded some, taking it as a show of loyalty and 'patriotism'. Acts of brutality and disrespect for the people's dignity and human rights started in colonial times. ${ }^{17}$ As far back as the colonial times, the Nigerian police officers were killing and maiming people as well as depriving them of their rights. They became 'a symbol of dictatorial establishment'. ${ }^{18}$

\section{i. $\quad$ Torture by NPF}

Unfortunately, police brutality did not end with the colonial regime. Political instability and authoritarianism in post-colonial Nigeria established a 'tradition of unaccountable governments and cemented the culture of police brutality'. ${ }^{19}$ Research conducted among 882 police detainees across the country during the military regime revealed that 'nearly half of the accused persons interviewed (48.7 percent) stated that their arrest involved insult or abuse by the police. A significant 35.9 percent were roughly handled or slapped; 7.4 percent were beaten with a baton; and three percent were threatened with a gun'. ${ }^{20}$

However, police brutality persisted after military rule. Research conducted by Amnesty in 2014, 15 years after the end of military rule, revealed that police

14 Nmerole C, Police interrogation in criminal investigation, Halygraph, Minna, 2008, 12-14.

15 Alemika E and Chukwuma I, 'Police-community violence in Nigeria', 5(2) Siren Journals, $2000,18$.

See, Ekwonwa M 'The Nigerian Police and crime prevention and control for good governance:

Challenges and prospect', 5 Siren Journals 2, 2000 available at < http://sirenjournals.com/index.php/ journals?id=183> on 21 May 2016.

16 For further reading on the history and evolution of the Nigerian Police Force see Tamuno T, The Police in Modern Nigeria, Ibadan University Press, Ibadan, 1970.

17 - <http://www.nigeriapolicewatch.com/resources/about.the.nigeria-police/> on 26 May 2016.

18 Onoge O, Social conflicts and crime control in colonial Nigeria, Ibadan University Press, Ibadan, $1993,178$.

19 Open Society Justice Initiative, Criminal force: Torture, abuse, and extrajudicial killings by the Nigeria Police Force, Open Society institute, New York, 2009, 30.

20 Ajomo $\mathrm{M}$ and Okagbue I, Human rights and criminal justice administration in Nigeria, Nigerian Institute of Advanced Legal Studies, Lagos, 1991, 122. 
brutality remains a regular occurrence in the operations of NPF. ${ }^{21}$ Joint research conducted by the Nigerian Human Rights Commission and the Centre for Law Enforcement Education (CLEEN) revealed that about 80 percent of inmates in police detention had either been beaten or threatened with weapons. ${ }^{22}$

This abuse is so commonplace and widespread that police interrogation rooms have been nicknamed 'torture rooms ${ }^{23}$ and the officers in charge $(\mathrm{O} / \mathrm{C})$ are called ' $\mathrm{O} / \mathrm{C}$ Torture'. ${ }^{24}$ The UN Special Rapporteur on Torture, after a visit to several Criminal Investigation Department detention facilities in Nigeria, noted that it is difficult to find a police detainee in Nigeria who had not been tortured. ${ }^{25}$ Extrajudicial executions, killing of suspected criminals, ${ }^{26}$ excessive and arbitrary use of force, and deaths in custody are all too common in the operations of the Nigerian police. ${ }^{27}$ This brutality is inflicted by NPF at all levels of police work ranging from 'crowd control, arrest, investigation, to detention'. ${ }^{28}$

Examples of brutality inflicted by the Nigerian police include dragging of suspects across the road; molestation; beating of detainees with rifle butts, rods and cables while suspended with a rope; nail, tooth, fingernail and toenail extractions; starvation; sitting on sharp nails and throwing hot water on wounds; shootings in the leg, foot or hand; water torture and rape. ${ }^{29}$ Even though these acts amount to prima facie violations of international prohibition against torture and other cruel, inhuman or degrading treatment, ${ }^{30}$ it is necessary to engage in legal analysis in order to demonstrate that these acts constitute torture and other cruel, inhuman or degrading treatment, especially as defined within the CAT.

21 Amnesty International, Welcome to bell fire: Torture and other ill-treatment in Nigeria, 18 September 2014.

22 Alemika and Chukwuma, Police-Community Violence in Nigeria, 51.

23 Amnesty International, Welcome to hellfire, 6

24 Maja-Pearce A, 'Changing Nigeria's cruel police culture', The New York Times, 7 October 2014.,

25 Report of the UN Special Rapporteur on torture adn other cruel, inhuman and degrading treatment in his mission trip to Nigeria, Juan Mendez, UN Doc A/HRC/7/3, para 12.

26 UNDP Common country assessment Nigeria, March 2001, 26; available at $-<$ www.undg.org/archive_ docs/1741-Nigeria_CCA_-_Nigeria_2001.zip> on 17 May, 2016

27 Report of the Special Rapporteur on extrajudicial, summary or arbitrary executions, Christopher Heyns, UN Doc A/HRC/8/3/2008, para 68.

28 Alemika and Chukwuma, Police-community violence in Nigeria, 21.

29 Amnesty International, Welcome to bellfire; The UN Special Rapporteur on Torture also confirmed these practices in his Report on his mission trip to Nigeria.

30 Dragan Dimitrijevic v. Serbia and Montenegro, United Nations Committee against Torture, Comm No. 207/02, (24 November 2004) para 2.1 and 5.3; Ireland v. the United Kingdom, European Court of Human Rights judgement of 18 January 1978; African Commission of Human Rights, Malawi African Association and Others v. Mauritania, Comm. Nos. 54/91 (2000), para 20. 


\section{Nigerian Law on Torture}

Regrettably, there is no law in Nigeria whose sole objective is the prohibition and punishment of torture and other forms of cruel, inhuman or degrading treatment in Nigeria. However, Section 34 of the Constitution provides that:

(1) Every individual is entitled to respect for the dignity of his person, and accordingly

(a) No person shall be subject to torture or to inhuman or degrading treatment.

This provision of the constitution expressly outlaws torture or any inhuman or degrading treatment in Nigeria. The Nigerian constitution is the supreme law of the country and has binding force on all authorities and persons throughout Nigeria. ${ }^{31}$ Section 1(1) of the Constitution provides that the constitution 'shall have binding force on all authorities and persons throughout the Federal Republic of Nigeria'. This includes NPF and all other security or intelligence operatives within Nigeria. No person or authority has the right to subject another to torture or any cruel or inhuman treatment since the constitution has expressly prohibited such treatment. The constitution has thus placed a restriction on NPF in its operations. The police force is to operate within such limit that does not amount to torture or to inhuman or degrading treatment. To do otherwise would be unlawful and amount to a breach of the constitution.

However, the persistence of torture and other cruel, inhuman or degrading treatment despite Section 34 (1) (a) of the Constitution showing its inadequacy and ineffectiveness in preventing torture and other cruel, inhuman and degrading treatment in Nigeria. This inadequacy and ineffectiveness is further fuelled by the absence of any subsequent provision in the constitution which provides for the punishment of and remedies for any breach of the prohibition against torture and other cruel, inhuman and degrading treatment.

The Police Act functions as the primary law that regulates the operation of $\mathrm{NPF}^{32}$ There is nothing in this Act which prohibits police officers from inflicting torture and other forms of cruel, inhuman or degrading treatment on people in the carrying out of their duties and functions. The absence of such a prohibition leaves a wide gap in the regulation of police conduct which has led to the abuse of human rights by police officers. There have been calls from non-governmen-

\footnotetext{
Section 1(1), Constitution of the Federal Republic of Nigeria (1999).

Section 214, Constitution of the Federal Republic of Nigeria (1999).
} 
tal organisations for the amendment of this Act to reflect the present need for a better regulation of the nation's police force. ${ }^{33}$

The absence of adequate provisions within the national law of Nigeria providing for protection from torture and other forms of cruel, inhuman or degrading treatment leaves international treaty law as the only other source of protection from torture and other forms of cruel, inhuman or degrading treatment.

\section{International Law and Torture}

\section{i. Enforcement of International Law in Nigeria}

Generally, the application of a treaty within a state follows either of two approaches: monism or dualism, which represent two perspectives that dictate the relationship between national law and international law. ${ }^{34}$ Monism views international and national law as part of a single legal order. ${ }^{35}$ An international treaty becomes directly applicable within the national legal order. ${ }^{36}$ There is no need for a domestic legislation to bring it within the national legal order. Dualism, on the other hand, places domestic and international law under two separate legal orders. ${ }^{37}$ Until an international treaty is passed as a domestic law, it has no force of law within the country and an individual within the State cannot rely on or benefit from its provisions. ${ }^{38}$

Nigeria adopts the dualist system. Section 12 of the Constitution provides that 'no treaty between the federation and any other country shall have the force of law except to the extent to which any such treaty has been enacted into law by the National Assembly. ${ }^{39}$ The Supreme Court of Nigeria reiterated this principle in Fawebinmi v Abacha when it held that 'an international treaty has no such force

33 Centre for Law Enforcement Education Foundation, Review of the Nigerian Police Act, 1943: Legal diagnosis and draft bill, Lagos, 2009.

34 Pierre-Hugues V and Versteeg M, Modes of domestic incorporation of international law, 15 Public Law and Legal Theory Research Paper Series, 2016, 2.

35 Duru O, International law versus municipal law: A case study of six African countries; Three of which are monist and three of which are dualist, 6 available at $<$ http: / / ssrn.com/abstract $=2142977>$ on 28 May, 2016.

36 Oppong R, 'Re-imaging international law: An examination of recent trends in the reception of international law into national legal systems on Africa,' 30(2) International Law Journal, 297.

37 Duru O, International Law, 7.

38 Ayewa S, The symmetry between international law and municipal law: A Nigerian Perspective, Delta State University Public Law Series, 2004, 85.

39 Section 12, 'Constitution of the Federal Republic of Nigeria', (1999). 
of law as to make its provisions justiciable in our courts ${ }^{340}$ until such a treaty is domesticated as a national law. An international treaty does not have the force of law in Nigeria it has been passed as national legislation. ${ }^{41}$ The implication of this is that even though Nigeria has ratified treaties such as the CAT, ICCPR and ACHPR, victims of torture cannot rely on any of these treaties for the enforcement of their rights. They can only avail themselves of the provisions of these treaties if they have been enacted as domestic law by the National Assembly. ${ }^{42}$ Unfortunately, the CAT which is the flagship treaty on torture is yet to be ratified as a national law in Nigeria.

Thus, a victim of torture and other cruel, inhuman and degrading treatment in Nigeria is left without an adequate means of redress to protect their right not to be subjected to torture and other forms of cruel, inhuman or degrading treatment. There is a lack of sufficient provisions within national law and the international law provisions cannot be enforced until they are enacted as national law.

\section{ii. Torture under International Law}

The prohibition against torture and other cruel, inhuman or degrading treatment abounds in many international and regional treaties. ${ }^{43}$ However, for the purpose of this article, focus will be placed on the prohibition as provided in the CAT, the ICCPR and the ACHPR, to which Nigeria is party.

Article 2(1) of the CAT provides that: 'Each State Party shall take effective legislative, administrative, judicial or other measures to prevent acts of torture in any territory under its jurisdiction'. ${ }^{44}$

The ICCPR expressly prohibits torture and other cruel, inhuman or degrading treatment or punishment. Article 7 of the ICCPR provides that: 'No one shall be subjected to torture or to cruel, inhuman or degrading treatment or punishment'. ${ }^{45}$

Abacha and others v Fawebinmi (2001) Supreme Court of Nigeria.

Section 12, Constitution of the Federal Republic of Nigeria, (1999).

42 Reliance was placed on the African Charter on Human and Peoples' Right in Abacha and Others v Fawehinmi (2001) Supreme Court of Nigeria. Because same had been passed into law by the National Assembly.

43 Article 5, Universal Declaration of Human Rights, 10 December 1948, 993 UNTS 3, Article 2 United Convention Against Torture, Article 7 of the International Convention on Civil and Political Rights, 213 UNTS 221,Article 5, African Charter on Human and People's Rights, Article 3 of the European Convention on Human Rights, Article 5 of the American Convention on Human Rights, 1144 UNTS 123.

44 Article 1 (2), United Nations Convention against Torture, 1465 UNTS 85.

45 Article 7, International Covenant for Civil and Political Rights, 999 UNTS 171. 
The ACHPR also provides that:

'Every individual shall have the right to the respect of the dignity inherent in a human being and to the recognition of his legal status. All forms of exploitation and degradation of man particularly slavery, slave trade, torture, cruel, inhuman or degrading punishment and treatment shall be prohibited'. ${ }^{46}$

Although these treaties prohibit torture, cruel, inhumane or degrading treatment, only one of these treaties provides a definition of these treatments or the acts that constitute them. The CAT provides the definition of torture as:

'.. any act by which severe pain or suffering, whether physical or mental, is intentionally inflicted on a person for such purposes as obtaining from him or a third person information or a confession, punishing him for an act he or a third person has committed or is suspected of having committed, or intimidating or coercing him or a third person, or for any reason based on discrimination of any kind, when such pain or suffering is inflicted by or at the instigation of or with the consent or acquiescence of a public official or other person acting in an official capacity. It does not include pain or suffering arising only from, inherent in or incidental to lawful sanctions'. ${ }^{47}$

It is important to state from the onset that there are no precise categorisations of what acts constitute torture or other cruel, inhuman or degrading treatment or punishment. The facts of each case determine whether the act or collective acts meet the requisite threshold to amount to torture or other cruel, inhuman or degrading treatment. ${ }^{48}$ The Human Rights Committee in assessing alleged violations of Article 7 of the ICCPR stated that:

'.. what constitutes inhuman or degrading treatment falling within the meaning of Article 7 depends on all the circumstances of the case, such as the duration and manner of the treatment, its physical or mental effects as well as the sex, age and state of health of the victim'. ${ }^{49}$

The Committee went further to state that the aim of Article 7 of the IC$\mathrm{CPR}$ is to protect both the dignity and the physical and mental integrity of the individual. ${ }^{50}$ Thus, any act which violates a person's dignity and/or his physical and mental integrity will, generally speaking, constitute a breach of international law against torture or other cruel, inhuman or degrading treatment.

\footnotetext{
Article 5, African Charter on Human and Peoples' Rights.

Article 1, United Nations Convention Against Torture.

48 Association for the Prevention of Torture, Torture in International Law: A guide to jurisprudence, 2008, 7-8.

49 Antti Vuolanne v Finland, CCPR Comm. No. 265/1987, (27 July 1989) 311.

50 CCPR General Comment No. 20: Article 7 (Probibition of Torture, or Other Cruel, Inbuman or Degrading Treatment or Punishment), 10 March 1992, - < http://www.refworld.org/docid/453883fb0.html on 24 May 2016.
} 
However, for an act to amount to torture the following elements must be established:

i. Severity of physical or mental pain or suffering caused to the victim ${ }^{51}$

ii. Intentionally inflicted ${ }^{52}$

iii. Specific purposes ${ }^{53}$

iv. Consent or acquiescence of a public official or other person acting in an official capacity $^{54}$

These elements are discussed below in application to the Nigerian situation:

\section{iii. Severity of mental or physical pain}

It has been established that the infliction of severe pain or suffering will amount to torture or other cruel, inhuman or degrading treatment. ${ }^{55}$ Even though the courts are yet to establish a clear-cut threshold of severity that differentiates torture from other cruel, inhuman or degrading treatment, there is an agreement that in the hierarchy of pain-inducing acts, torture stands at the apex. ${ }^{56}$ It is clear that the brutality being inflicted by the Nigerian police is so severe that deaths often result from these acts. ${ }^{57}$ This attests to the severity of the pain and suffering being inflicted by the Nigeria police upon the victims. Even when such acts do not lead to death, it is enough that they inflict severe pain upon the victim. The victim's 'point of view' must be a factor in determining the severity of an act. ${ }^{58}$ In determining the severity or gravity of an act, there must be an appraisal of its effect or impact on the particular victim and not a mere analysis which takes no consideration of the particular victim involved. ${ }^{59}$ For example, what constitutes the torture of a woman who is eight months pregnant may not amount to torture for a 25 year old athletic man. This is due to the fact that the same act of torture

51 Prosecutor $v$. Delalic et al., International Criminal Tribunal of the Former Yugoslavia, 468; Ireland $v$. United Kingdom, European Court of Human Rights, para 167.

52 Selmouni v. France, ECtHR Judgement of 28 July 1999, para 403, 426. See as well, Hathaway O, Nowlan A and Spiegel J, 'Tortured reasoning: The intent to torture under international and domestic law', 52(4), Virginia Journal of International Law, 2012, 791-837, 801.

53 Prosecutor v. Delalic, International Criminal Tribunal of the Former Yugoslavia, 470.

54 Article 1, United Nations Convention against Torture,Prosecutor v. Delalic, ICTY, 473.

55 Prosecutor $v$. Delalic, International Criminal Tribunal of the Former Yugoslavia, 470; Ireland v. United Kingdom, ECtHR, 167.

56 Miller G. Defining torture, Floersheimer Center for Constitutional Democracy, New York, $2005,8$.

57 Amnesty International, Welcome to bellfire, 19,40,42,43.

58 Cullen A, 'Defining torture in International law: A critique of the concept employed by the European Court of Human Rights', 34 California Western International Law Journal, 33.

59 Ingelse C, The UN Committee against Torture: An assessment, Kluwer Law International, The Hague, 2001,209 . 
may inflict a different level of pain on the pregnant woman than it would on the young man. In summary, the threshold is subjective and not easily determinable.

\section{iv. Intention}

The harm inflicted must be intentional. ${ }^{60}$ The mens rea for torture is met by evidence that the accused intentionally inflicted severe pain or suffering on a person. ${ }^{61}$ The acts and extent of brutality inflicted by the Nigerian police demonstrate cases of well-thought out acts, rather than acts arising out of mistake or negligence. ${ }^{62}$ The existence of dedicated torture chambers in Nigeria's Criminal Investigation Departments ${ }^{63}$ also proves the fact that these brutalities are inflicted with intention rather than as mistakes.

Furthermore, intention will be presumed where an individual is taken into police custody in good health but returns injured and it becomes incumbent upon the State to provide a plausible explanation of how those injuries were caused. ${ }^{64}$ The return of several police detainees with injuries, ${ }^{65}$ and in some cases permanent deformities, places the onus on Nigeria to prove that its police force does not intentionally inflict brutality on its detainees.

\section{v. Purpose}

In order for an act to amount to torture, it must have been inflicted for the purpose of achieving one or more of the following prohibited purposes: obtaining information; punishing; intimidating or coercing; or for any reason based on discrimination of any kind. ${ }^{66}$

For an act to constitute torture, there must be a targeted end in mind, which motivates the infliction of pain on the victim. ${ }^{67}$ The brutality inflicted by the Nigerian police is not only intentional but it is usually inflicted for one or more of the prohibited purposes. It has been shown on several occasions that the police inflict these brutalities as a means of either punishing or getting information or

\footnotetext{
60 Article 1 United Nations Convention Against Torture.

61 Hathaway O, Nowlan A and Spiegel J, Tortured reasoning: The intent to torture underinternational and domestic law, 801.

62 Human Rights Watch, Rest in Pieces: Police Torture and Deaths in Custody in Nigeria, Human Rights Watch, New York, 2005, 27.

63 Amnesty International, Welcome to Hellfire, 6.

64 Selmouni v. France, European Court of Human Rights, 403, 426.

65 Amnesty International, Welcome to Hellfire, 13.

66 Article 1, United Nations Convention against Torture.

67 Miller, Defining Torture, 16.
} 
confessions from their victims ${ }^{68}$ Detainees are beaten and brutalised until they confess to offences (which they probably did not commit). ${ }^{69}$ At other times, they are made to sign confessional statements which have been written beforehand by a police officer. ${ }^{70}$ The fact that there is a prohibited purpose brings these acts within the definition of torture under international human rights law.

\section{vi. Consent of a public official}

It has been established that even the most heinous acts or inhuman treatment inflicted by an individual will not be considered as torture. ${ }^{71}$ The focus of torture under international human rights law is on acts being perpetrated by agents of the state and in 'respect of which the machinery of investigation and prosecution might therefore not function normally'. ${ }^{72}$ The acts of brutality under discussion are being inflicted by NPF. ${ }^{73}$ They do not act under any guise. These acts are perpetrated in their official capacity and as a means of operating.

\section{vii. Other prohibited treatments: Cruel, inhuman or degrading treatment}

Where an act of police brutality fails to meet one or more of these criteria and does not rise to the threshold level of torture, it may nevertheless amount to other cruel, inhuman or degrading treatment. ${ }^{74}$ This refers to all other acts of the police which, though not constituting torture, amount to an excessive use of force by the police. ${ }^{75}$ These include acts which are aimed at humiliating the victim even where severe pain has not been inflicted. ${ }^{76}$ Article 16 of the CAT places an obligation on state parties to 'prevent other acts of cruel, inhuman or degrading treatment' even if such acts do not amount to torture. ${ }^{77}$

The European Court of Human Rights thus held in Ireland v. United Kingdom that although acts like wall-standing, hooding, subjection to noise, reduced diet and deprivation of sleep did not amount to torture, they constituted inhuman

\footnotetext{
68 Open Society Justice Initiative Criminal Force, 35, Amnesty International, Welcome to Hellfire, 6.

69 Open Society Justice Initiative Criminal Force 37.

70 Amnesty International Welcome to Hellfire, 5, 23.

71 Miller, Defining Torture, p 17.

72 Wendland L, A bandbook on state obligations under the UN Convention against Torture, Association for the Prevention of Torture, Geneva, 2002, 28-29.

73 Section 214, Constitution of the Federal Republic of Nigeria (1999).

74 Prosecutor v. Delalic, International Criminal Tribunal for the Former Yugoslavia, 468.

75 Nowak M and McArthur E, The distinction between torture and cruel, inhuman or degrading treatment,16(3) Torture, 2006, 146.

76 Report of the Special Rapporteur on the question of torture, 23 December 2005, UN Doc E/CN 4/2006/6, 12 .

77 Nowak and McArthur, The Distinction between Torture and Degrading Treatment, 148.
} 
and degrading treatment. ${ }^{78}$ Thus, bearing in mind that what amounts to police brutality is the excessive use of force by the police, ${ }^{79}$ every act of the police which constitutes excessive and abusive use of force, even if not amounting to torture, will fall under the other types of prohibited treatments.

\section{Torture under the African Charter on Human and Peoples Rights}

As mentioned earlier, the ACHPR also prohibits torture and other forms of inhuman treatment. The Charter is enforced by the African Commission on Human and Peoples' Rights (the Commission) ${ }^{80}$ and the African Court on Human and Peoples' Rights. ${ }^{81}$ Article 1 of the ACHPR places an obligation on state parties to create such measures-legislative and administrative- to ensure compliance with the provisions of the Charter. Thus, every state party to the ACHPR has an obligation to ensure that all individuals within its jurisdiction and authority are protected from torture and other forms of inhuman treatment. This is evident in the decision of the Commission in Commission Nationale des Droits de l'Homme et des Libertes v Chad, where the Commission held that the failure of the Chadian government to protect its citizens from torture constituted a breach of the State's obligation under Article 5 of the ACHPR. ${ }^{82}$

One of the options that the Charter expressly provides for as measures to be taken by states is the enactment of domestic laws prohibiting and criminalising torture and other forms of inhuman treatment. ${ }^{83}$ The Commission in expounding on this provision has made it clear that the mere existence of domestic legislation will not suffice, states must ensure the effective functioning of such legislation and its enforcement to the extent that any incidents of torture and other inhuman treatment are investigated and prosecuted..$^{84}$

${ }^{78}$ Ireland v. United Kingdom, European Court of Human Rights, 167-168.

79 Carter D, Theoretical dimensions in the abuse of authority by public officers, 7(4) Police Studies, 1984, 224-236.

80 Article 30, African Charter on Human and People's Rights, 1520 UNTS 217.

81 Article 1, Protocol to the African Charter on Human and Peoples' Rights on the Establishment of an African Court on Human and Peoples' Rights.

82 Commission Nationale des Droits de l'Homme et des Libertes v Chad, AfrCommHPR, Comm No. 74/1992, Activity Report (1995), Purohit and Moore v The Gambia, AfrCommHPR, Comm No. 241/2001, 16 Activity Report (2003).

83 Article 1 and 5, African Court on Human and Peoples' Rights.

84 Zimbabwe Human Rights NGO Forum v Zimbabwe, African Commission on Human and People's Rights, Comm No. 245/2002, 21 Activity Report (2006) 159; Amnesty International and Others v Sudan, African 
The Commission has also interpreted state obligation under Article 1 of ACHPR to include an obligation to compensate victims of abuses. In Zimbabwe Human Rights NGO Forum v Zimbabwe, the Commission held that the obligation to respect and protect means that 'any person whose rights are violated would have an effective remedy as rights without remedies have little value'. ${ }^{85}$ The right to compensation is not affected by the existence or absence of a prosecution in the said case. ${ }^{86}$ Thus, a victim will be entitled to compensation whether or not the perpetrator is being tried. Thus, Nigeria as a party to the ACHPR has an obligation to compensate those who have suffered one form of torture or the other in the hands of the police. Without such compensation in place, the State cannot be said to be protecting the rights of its citizens and fulfilling its obligation under the ACHPR.

It must be noted that unlike the CAT and the ICCPR, the ACHPR has been passed as a domestic law in Nigeria. ${ }^{87}$ This implies that its provisions are enforceable in the country and before the national courts in the same manner as a domestic law is. Thus, the obligation of Nigeria under the Charter is double-fold. Nigeria is obliged under the Charter both as an international instrument and as a national law. In Fawenhinmui v Abacha, the Supreme Court of Nigeria held that having been passed into domestic law, 'the Charter possesses a greater vigour and strength than any other domestic statute'. ${ }^{88}$ Despite this affirmation by the apex court of the country and the undertaking by the government of Nigeria in its fifth periodic country report, ${ }^{89}$ it is sad to note that the provisions of this Charter are yet to be implemented by the government of Nigeria. Nigeria remains in continued violation of its international obligations.

The Commission has a responsibility to ensure compliance with the $\mathrm{ACH}$ PR but is handicapped by the fact that it lacks the power to enforce its decisions. A decision of the Commission is to be treated with confidentiality and can only be made public upon the permission of the Assembly of Heads of States and

Commission on Human and People's Rights, Comm Nos. 48/1990, 50/1991, 52/1991, 89/1993, 13 Activity Report (1999), 56.

85 Zimbabwe Human Rights NGO Forum v Zimbabwe, 171.

86 Association for the Prevention of Torture, Guidelines and Measures for the Probibition and Prevention of Torture, Cruel, Inbuman or Degrading Treatment or Punishment in Africa, 2008, Article 50,.

87 African Charter on Human and Peoples' Rights (Ratification and Enforcement) Act (Cap. A 9 of Nigeria.

88 Fawebinmiv Abacha, para 15.

89 Federal Ministry of Justice, Nigeria's 5th Periodic Country Report: 2011-2014 On the Implementation of the African Charter on Human and Peoples' Rights in Nigeria. 2014. In this report, Nigeria undertook to domesticate all human rights treaties. It has been 30 months since this report and none of these treaties has been domesticated. 
Governments. ${ }^{90}$ The subjection of the Commission to a political arm of the African Union makes it impossible to guarantee its impartiality in the discharge of its functions and responsibilities. A state also enjoys protection from public scrutiny and media pressure even when it has been decided that such a state is guilty of the contravention of the provisions of the ACHPR.

\section{Force Order 237 and the Exemption of Lawful Sanctions}

Certain acts are exempted from the definition of torture and other cruel, inhuman or degrading treatment even if they seem to meet the criteria. An act will not constitute torture or other cruel, inhuman or degrading treatment where the pain or suffering inflicted arises from, is inherent in or incidental to lawful sanctions. ${ }^{91}$ This exception taken literally connotes that a state is justified in inflicting pain or such other acts which ordinarily would have amounted to torture if such acts are recognised and permitted under the national law of the state. This provision leaves a loophole in international human rights law as regards torture and creates ambiguities. ${ }^{92}$ It weakens the universality of the definition of torture by introducing exceptions based on national law. ${ }^{93}$ This exception creates an avenue for states to legitimise certain acts under the guise of national law ${ }^{94}$ and perpetrate torture and other cruel, inhuman or degrading treatment under such laws.

However, what amounts to 'lawful sanctions' within a state must conform to 'practices that the international community widely accepts as permissible sanctions'. ${ }^{95}$ Lawful sanction is to be defined in terms of internationally accepted standards rather than what is applicable within a state. ${ }^{96}$ Thus, an exception based on 'lawful sanction' will not be valid if such acts fall below the minimum standard permissible under international law. For example, Article 4 of the Basic Principles on the Use of Force and Firearms by Law Enforcement Officials provides that lethal force shall only be used as a means of last resort. ${ }^{97}$ Thus, a national law

\footnotetext{
90 Article 59, African Charter on Human and People's Rights, 1520 UNTS 217.

91 Article 1, United Nations Convention Against Torture.

92 Boulesbaa A, The UN Convention on Torture and the prospects for enforcement, Kluwer Law International, The Hague, 1999, 32.

93 Miller, Defining Torture, 21.

94 Miller, Defining Torture, 20.

95 Report of the Special Rapporteur on the question of the buman rights of all persons subjected to any form of detention or imprisonment, Nigel S.Rodley, 13 December 1996, UN Doc E/CN.4/1997/7.

96 Report of the Special Rapporteur on the question of the buman rights of all persons subjected to any form of detention or imprisonment.

97 UN Congress on the Prevention of Crime and the Treatment of Offenders, Basic principles on the use of force and firearms by law enforcement officials 7 September 1990.
} 
permitting the use of lethal force other than as a last resort will not be regarded as an exception as it does not meet international standards regarding the use of lethal force.

Police Force Orders are policies, police administrative and operational procedure and records made by the Inspector General of Police to regulate activities of police personnel within the force. Force Order 237 (Rules for guidance in use of firearms by the police ${ }^{98}$ permits a police officer to use firearms under the following conditions:

'If he cannot by any other means arrest a person who being in lawful custody escaped and took to flight in order to avoid re-arrest, provided the offence with which he is charged or has been convicted of is a felony or misdemeanour.

If he cannot by any other means arrest a person who takes to flight in order to avoid arrest, provided the offence is such that the accused may be punished with death or imprisonment for seven years and above. ${ }^{99}$

This order empowers police officers to shoot suspects and detainees who attempt to escape or evade arrest, ${ }^{100}$ irrespective of whether or not such a person poses a threat to life. ${ }^{101}$ Section 6 of Police Force Order goes further to permit the police to single out and fire at the ring-leaders of riots. ${ }^{102}$ This Order provides a broad exception to the use of firearms by members of the police force. ${ }^{103}$ It is contrary to international standards guiding the use of firearms by the police, and it does away with the international standard requirement of 'imminent threat of death or serious injury'. Force Order 237 establishes a low threshold of necessity for the permissibility of the use of firearms by NPF than is known under international law. Principle 9 of the UN Basic Principles on the Use of Force and Firearms, for example, permits the lethal use of firearms only when it is 'strictly unavoidable in order to protect life'. ${ }^{104}$

98 Force Orders are policies, police administrative and operational procedure and records made by the Inspector General of Police to regulate activities of police personnel within the force.

$99 \quad$ Section 3 (d) \& (e) Police Force Order 237, Nigeria.

100 Amnesty International, Policing and justice in Nigeria, $-<$ http://www.eyesonnigeria.org/EON_Justice. html> on 23 May, 2016.

101 Amnesty International, Killing at will extrajudicial executions and other unlawful killings by the police In Nigeria, London, 2009, 16.

102 Section 6, Police Force Order 237, Nigeria.

103 Amnesty International, Killing at will extrajudicial executions and other unlawful killings by the police in Nigeria, 16.

104 United Nations Congress on the Prevention of Crime and the Treatment of Offenders, Basic principles on the use of force and firearms by law enforcement officials, 7 September 1990. 
Force Order 237 has been used by the Nigerian police as a front for brutality. ${ }^{105}$ The former Attorney General and Minister of Justice made this clear in a national dialogue when he stated that the police had, through the years, relied on 'Police Force Order 237 ' to commit extrajudicial killings. ${ }^{106}$ According to him, the police had perpetrated unlawful killings of 7,195 persons in four years. ${ }^{107}$ The reliance placed on Force Order 237 by the police is not valid as it amounts to a violation of international standards regarding the use of force. Force Order 237 must be regarded as void vis-à-vis Nigeria's obligation under international treaty law. Article 27 of the Vienna Convention provides that a state 'may not invoke the provision of its internal law as justification for its failure to perform its obligations under a treaty'. ${ }^{108}$ 'Thus, a provision in the national legal system cannot be a valid ground for violating an international treaty obligation.

Such an order which empowers and makes it lawful for the police to engage in the indiscriminate murder is not a lawful exemption to the prohibition of torture and other cruel, inhuman or degrading treatment. It does not conform to international standard on the use of lethal force and contravenes express international treaty provisions. ${ }^{109}$ Any reliance on Force Order is an illegality and a contravention of both national and international law.

\section{In Lieu of Conclusion}

As earlier stated, Nigeria practices a dualist system in its approach to state enforcement of international treaties. Unfortunately, Nigeria is yet to domesticate the UNCAT; neither does it have an anti-torture law. This leaves a loophole in terms of holding Nigeria accountable for torture and other cruel, inhuman or degrading treatment being perpetrated by its police force. Nigeria cannot be held accountable or compelled to perform any of its obligations under the UNCAT. What then is the way forward for ensuring accountability and ending a culture of impunity and lack of concern?

\footnotetext{
105 Amnesty International), Killing at will extrajudicial executions and other unlawful killings by the police In Nigeria, 17. Centre for Law Enforcement Education Foundation, Enhancing accountability systems in the Nigeria Police Force, Conference Proceedings Monograph Series 8. Lagos, 2010, 30-32.

106 'Adoke confirms our worst fears', The Nation online, 12 December 2012 available at -<http://thenationonlineng.net/adoke-confirms-our-worst-fears/> on 27 May 2016.

107 'Adoke Confirms Our Worst Fears'.

108 Article 27, Vienna Convention on the Law of Treaties, 23 May 1969, 1155 UNTS 331.

109 Article 7, International Convenant on Civil and Political Rights, Article 2 (1), United Nation Convention against Torture and Article 5, African Charter on Human and People's Rights.
} 
Firstly, there is a need to enact a law prohibiting torture by officers of the police force and other state security agencies. This law should provide a specific legal framework for the prohibition of torture and other cruel, inhuman or degrading treatment in the operations of the police and for the adequate compensation of victims of such acts. This anti-torture law should state and establish that the prohibition against torture is non-derogable. The fact that the police or any other security or intelligence service in Nigeria considers a person as a suspect of a crime does not remove the prohibition against torture and other prohibited treatment. The existence of such a law which primarily deals with torture and other cruel, inhuman or degrading treatment would help put in place the necessary legal framework for protection from torture and other cruel, inhuman or degrading treatment. This would in turn ensure the protection of the rights of the potential victims of such ill treatment and enable the punishment of those responsible. This law should also provide a legal framework for the operation of the National Committee on Torture. It is worthy to note that there is an antitorture bill currently under review at the National Assembly. Unfortunately, this bill, known as the Bill for an Act Penalising the Commission of Acts of Torture and other Cruel, Inhuman and Degrading Treatment or Punishments ${ }^{110}$ has been in the legislative process since $2012^{111}$ and is yet to be enacted by the legislature.

Furthermore, there is a need to domesticate the UNCAT. This will help to ensure that its provisions gain the force of law in Nigeria. Once Nigeria domesticates this treaty, it will open an avenue to hold Nigeria accountable for torture and other prohibited acts being perpetrated by its police force. It will create a sense of responsibility on the part of the police force. The domestication of this treaty will also create a legal framework upon which victims of torture and other cruel, inhuman or degrading treatment can claim justice and compensation.

In addition, it is recommended that adequate human rights education be given to officers of NPF. Human rights education should be included in the curriculum of training in the police college. It has been reported that 'poor education and lack of emphasis on human rights' in their training has contributed to the continued practice of police brutality by NPF. ${ }^{112}$ The training of the police in the area of human rights would help reinforce the importance and inviolability of human rights into their general practice and attitude.

\footnotetext{
$110-<$ http://nass.gov.ng/document/bills $>$ on 28 May 2016.

111 - < https://www.amnesty.org/en/countries/africa/nigeria/ $\geq$ on 28 May 2016.

112 Okeshola F, Human rights abuse by Nigerian police in four selected states and the Federal Capital Territory, 13(2) British Journal of Arts and Social Sciences, 2013, 248; Innocent C, The legal structure of the police and human rights in Nigeria, 14 Third World Legal Studies, 1997, 69-70
} 
Lastly, there is a need for the Nigerian government to review Force Order 237. This Order, as earlier stated, has been a tool in the hands of NPF for perpetuating torture and other cruel, inhuman and degrading torture. Therefore, this order should be reviewed and made to conform to international standards on the use of lethal force, especially as provided for in the United Nations' Basic Principles on the Use of Force and Firearms by Law Enforcement Officials. It should be recalled that a national law must conform to international standards before it can be regarded as a lawful exemption to torture and other cruel, inhuman or degrading treatment. Force Order 237 should therefore be made to conform to international standards as a means of stopping the present practice of torture and other cruel, inhuman or degrading treatment in Nigeria.

The continued brutality being inflicted by the Nigerian Police shows a clear case of a Police Force engaged in torture. Such acts as dragging suspects across the road, molestation, beating of detainees with rifle butts, rods and cables while suspended with a rope, nail and tooth extractions, starvation, sitting on sharp nails and throwing hot water on wounds, shootings in the leg, foot or hand; extracting teeth, fingernails or toenails; water torture, rape, and the like. ${ }^{113}$ are clear cut instances of torture by the Nigerian police. This is despite the fact that Nigeria is party to international treaties prohibiting torture. Unfortunately, the provisions of these treaties cannot be upheld until they have been domesticated. Thus, Nigeria continues to breach its obligations under international law with regards to prohibition of torture.

In order to stop impunity and hold Nigeria accountable for these acts, there must be a legal framework in place as the existing laws have proven to be inadequate in preventing or punishing the present practice of torture being practiced by NPF. This framework can be provided for by the enactment of an anti-torture law and the domestication of the CAT. The establishment of a national committee against torture will also ensure that there is a body which serves as a regulator in the fight against torture and other prohibited treatments. This will lead the way in ensuring that police officers and Nigeria as a nation are held accountable for any act of torture and other cruel, inhuman or degrading treatment against individuals and especially those in police custody.

113 Amnesty International, 'Welcome to hellfire'. 